\title{
Electrophysiology of Mimosa pudica L
}

\author{
Ayngaran Adalarasu
}

Aug, 30, 2020

\begin{abstract}
Certain plants like the Mimosa pudica shows thigmonastic behavior. This is a nastic (rapid) behavior communicated via electrical impulses, called action potentials, within the plant. The motivation of our study is to observe the thigmonastic behavior of the M. Pudica plant by subjecting it to external electrical action potentials applied across the pulvinus and ground. And to find the minimum threshold required to trigger a thigmonastic response artificially in the plant. This observation has been conducted several times under varying specific conditions to find the exact minimum threshold charge that evokes the drooping of the petiole in the plant.
\end{abstract}

Keywords: Thigmonasty, Action potenital, Mimosa pudica, Minimum threshold charge, Electrical impulse, Pulvinus 


\section{Introduction}

Certain plants like Mimosa pudica show thigmonastic behavior. When their pinnae or petiole are touched or tapped, an electrical impulse (called an action potential) is generated via ionic imbalances and is transmitted through the petiole to the pulvinus. This action potential causes water to be expelled out of certain cells, which in turn causes a drop in turgor pressure. The shrinking of multiple cells at once causes mechanical stress, hence drooping of the petiole and closing of the pinnae.

Several [1, 2, 3] 4, 5],6] scientists have studied mechanical movements in M. pudica that were induced by an electrical impulse. Balmer and Franks (1975)2 briefly applied 200-400V between the soil and the primary pulvinus. They estimated that the threshold voltage to trigger a response in petiole was about $25 \mathrm{~V}$ with any electrode polarity. Jonas (1970) 3] gave an electrical shock to M. pudica using a $0.5 \mu \mathrm{F}$ capacitor charged by 50,100 , and $150 \mathrm{~V}$ and found that there were oscillations of pinnae and fast petiolar movement. Yao $\mathrm{H}$ et al. (2008) applied a $9 \mathrm{~V}$ electric pulse of $0.5 \mathrm{~s}$ duration to M. pudica and observed that the petioles bent downwards and the pinnae closed.

The motivation of this study is to find out whether the drooping effect in the $M$. pudica plant can be stimulated by an external artificial electrical signal of magnitude $9 \mathrm{~V}$, applied across the pulvinus and ground, and to ascertain the minimum activation charge. We have done this by subjecting the plant to electrical signals from a capacitor (charge bank) of different magnitudes and then finding the minimum amount of charge required to trigger a response.

We have carried out this experiment several times under various specific conditions to map the exact behavior of the plant.

\section{Principle}

The $M$. pudica exhibits thigmonastic behavior. When their pinnae or petiole are touched or tapped, an electrical impulse (called an action potential) is generated via ionic imbalances and is transmitted through the petiole to the pulvinus. This action potential causes water to be expelled out of certain cells, which in turn causes a drop in turgor pressure. The shrinking of multiple cells at once causes mechanical stress, hence drooping of the petiole and closing of the pinnae.

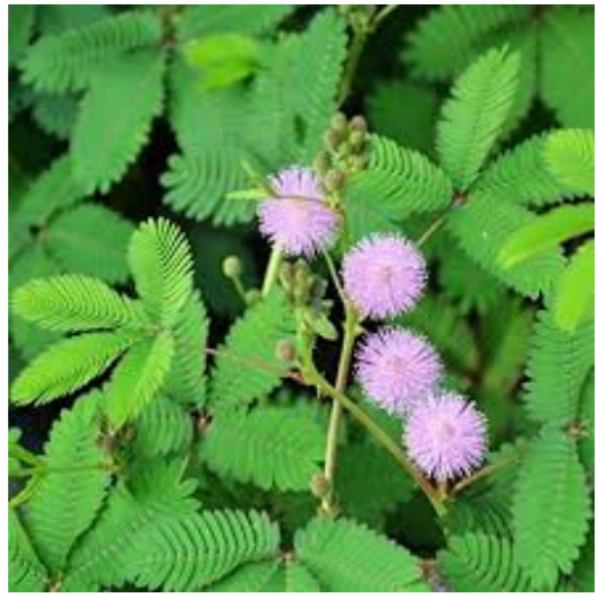

Figure 1: Mimosa pudica plant

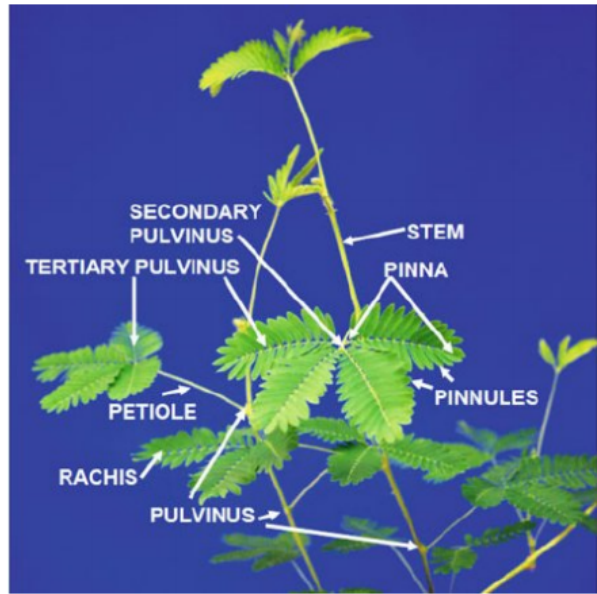

Figure 2

There are two behaviors an $M$. pudica plant exhibits when stimulated:

1. When its pinnae are gently touched - the pinnae are attached to that particular secondary pulvinus fold.

2. When the petiole is gently tapped - the whole petiole droops at the pulvinus node.

Once the plant has drooped its pinnae or petiole, the cells regain their turgidity after 5-10 minutes, and they return to their normal state slowly.

It has been observed that whenever any part of the plant (petiole or pinnae) is touched or tapped, the action potential evoked travels and converges at the pulvinus. Thus it would be appropriate to apply external electrical stimulus at that point for the experiment. 


\subsection{Circuit Principle}

We will be using a capacitor(a device capable of storing electrical charge) to transfer a fixed amount of electrical charge to the plant as an external artificial action potential. Different capacitors with different magnitudes of capacitance are charged with a $9 \mathrm{~V}$ battery and used to give electric impulse in the experiment.

$$
Q=C V
$$

$\mathrm{Q}=$ Charge stored in capacitor; $\mathrm{C}=$ Capacitance of capacitor; $\mathrm{V}=$ Potential difference

\section{Procedure}

The steps taken to perform the experiment have been summarised below,

1. Construct the circuit as shown in the circuit diagram (Fig.5)

2. Connect the cathode terminal to a nail and insert it into the soil of a potted M. pudica plant for grounding.

3. Gently wrap a piece of wire around the pulvinus of a stem, forming a loop. And then secure the wire firmly so that the setup is stable.

4. Connect the pulvinus wire to the anode terminal of the circuit.

5. Place the switch in the normally closed position for 5 seconds to charge the capacitor.

6. Then flip the switch to the normally open position to disconnect the battery and trigger the electrical signal.

7. Wait for a few seconds and record the behavior of the plant.

8. Wait for around an hour for the drooped stem to regain turgidity and return to its normal position.

9. Repeat the experiment (step 5 - step 8) using different capacitors with different magnitudes of capacitance $(470 \mu F, 1000 \mu \mathrm{F}, 1 \mu \mathrm{F}, 10 \mathrm{pF}, 100 \mathrm{nF}, 1 \mathrm{nF})$.

10. Repeat these series of experiments under different conditions and by reversing the polarity of output terminals. i.e., connecting the anode terminal to the ground of the plant and the cathode to the pulvinus.

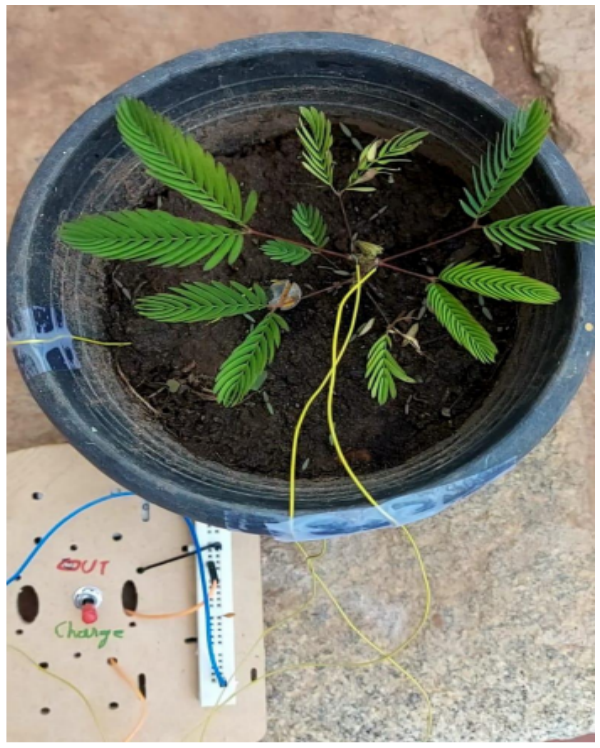

Figure 3: Complete experimental setup has beenFigure 4: Location of the electrodes on the plant has depicted in this picture

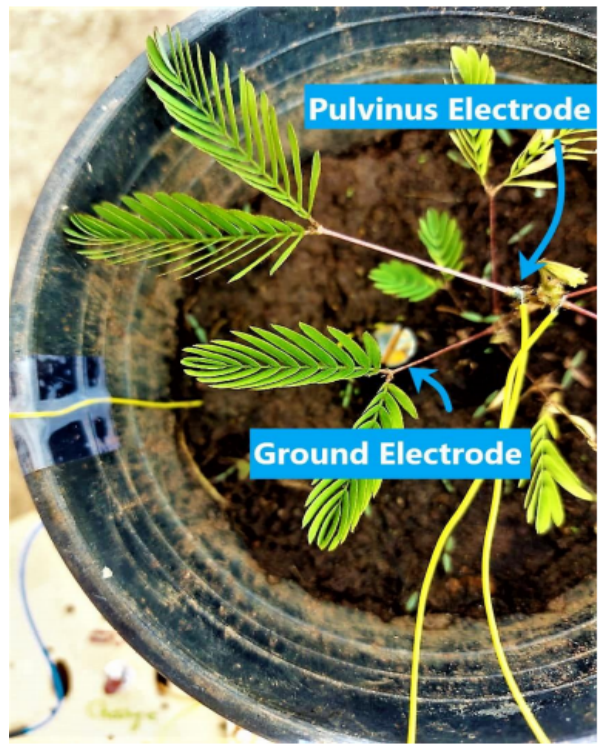

been identified in this figure 
Circuit Diagram The circuit consists of a capacitor, which is used to expose the plant to a fixed amount of electrical charge, a $9 \mathrm{~V}$ battery which acts as the primary power source to charge the capacitor, and a single throw double pole switch to alternate between two states- at one state it disconnects the plant and charges the capacitor while at the other, it disconnects the battery and transfers the electrical signal to the plant.

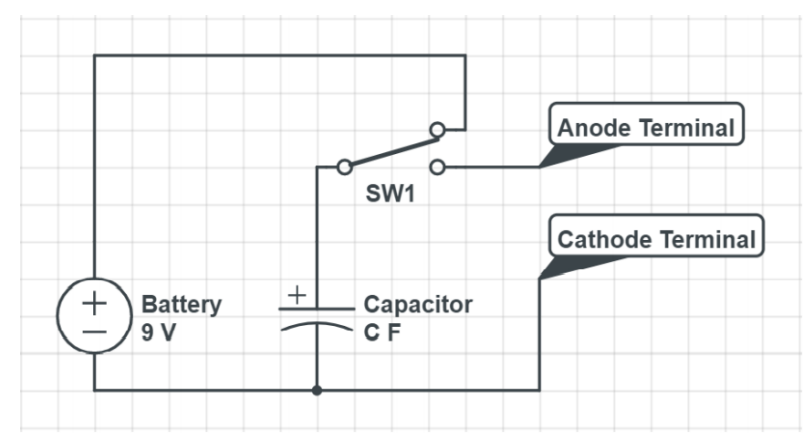

Figure 5: Circuit Diagram

\section{Results}

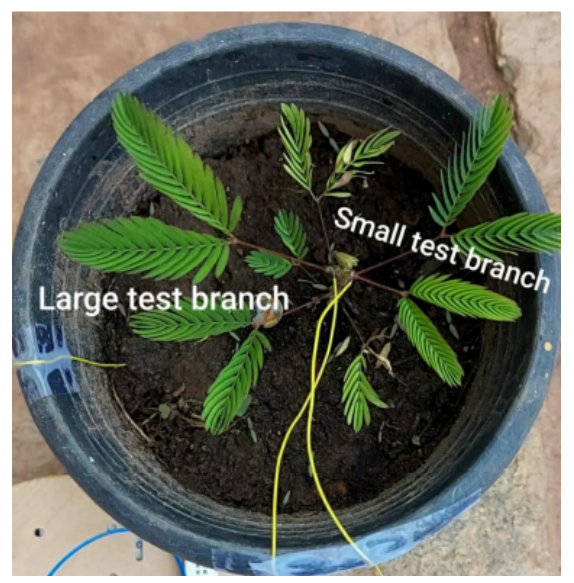

Figure 6: Branches used for experimentation are shown in this picture

These experiments were carried out on two particular branches of the live M. pudica specimen, and their behavior is summarized below.

\begin{tabular}{|c|c|c|c|c|c|c|c|}
\hline $\begin{array}{l}\text { Sl. } \\
\text { No }\end{array}$ & $\begin{array}{lr}\text { Time } & \text { Stamp } \\
(\mathrm{mm} / \mathrm{dd} & \text { at } \\
\mathrm{hh:mm}) & \end{array}$ & $\begin{array}{l}\text { Initial Status of } \\
\text { plant }\end{array}$ & $\begin{array}{l}\text { Volta: } \\
\text { (acros } \\
\text { pulviı } \\
\& \\
\text { groun }\end{array}$ & Capar & $\begin{array}{l}\text { Net } \\
\text { Charge } \\
\text { Given }\end{array}$ & $\begin{array}{l}\text { Plant Behavior } \\
\text { upon triggering }\end{array}$ & $\begin{array}{l}\text { Plant } \\
\text { Behavior } \\
\text { after } \\
\text { sometime }\end{array}$ \\
\hline 1 & $\begin{array}{l}26 / 8 \text { at } 10: 19 \\
\text { [Large } \\
\text { Branch] }\end{array}$ & $\begin{array}{l}\text { The plant is } \\
\text { healthy. Soil is } \\
\text { moderately moist }\end{array}$ & $-9 v$ & $470 \mu F$ & $4230 \mu C$ & $\begin{array}{l}\text { The branch } \\
\text { spontaneously } \\
\text { droops at } \\
\text { pulvinus. Leaves } \\
\text { do not droop }\end{array}$ & $\begin{array}{l}\text { The branch } \\
\text { became erect } \\
\text { after 10min }\end{array}$ \\
\hline 2 & $\begin{array}{l}26 / 8 \text { at } 13: 30 \\
\text { [Large } \\
\text { Branch] }\end{array}$ & $\begin{array}{l}\text { The plant is } \\
\text { healthy. Soil is } \\
\text { moderately moist }\end{array}$ & $-9 v$ & $470 \mu F$ & $4230 \mu C$ & $\begin{array}{l}\text { The branch } \\
\text { spontaneously } \\
\text { droops at } \\
\text { pulvinus. Leaves } \\
\text { do not droop }\end{array}$ & $\begin{array}{l}\text { The branch } \\
\text { became erect } \\
\text { after } 10 \mathrm{~min}\end{array}$ \\
\hline 3 & $\begin{array}{l}26 / 8 \text { at } 15: 00 \\
\text { [Large } \\
\text { Branch] }\end{array}$ & $\begin{array}{l}\text { The plant is } \\
\text { healthy. Soil is } \\
\text { less moist }\end{array}$ & $-9 \mathrm{v}$ & $470 \mu F$ & $4230 \mu C$ & $\begin{array}{l}\text { No changes are } \\
\text { observed }\end{array}$ & \\
\hline
\end{tabular}




\begin{tabular}{|c|c|c|c|c|c|c|c|}
\hline 4 & $\begin{array}{l}26 / 8 \text { at } 15: 00 \\
\text { [Large } \\
\text { Branch] }\end{array}$ & $\begin{array}{l}\text { The plant is } \\
\text { healthy. Soil is } \\
\text { less moist }\end{array}$ & $-9 \mathrm{v}$ & $1000 \mu F$ & $900 \mu C$ & $\begin{array}{l}\text { No changes are } \\
\text { observed }\end{array}$ & \\
\hline 5 & $\begin{array}{l}26 / 8 \text { at } 15: 00 \\
\text { [Large } \\
\text { Branch] }\end{array}$ & $\begin{array}{l}\text { The plant is } \\
\text { healthy. Soil is } \\
\text { less moist }\end{array}$ & $+9 \mathrm{v}$ & $470 \mu F$ & $4230 \mu C$ & $\begin{array}{l}\text { The branch } \\
\text { spontaneously } \\
\text { droops at } \\
\text { pulvinus. Leaves } \\
\text { do not droop. }\end{array}$ & $\begin{array}{l}\text { The branch } \\
\text { became erect } \\
\text { after 10min }\end{array}$ \\
\hline 6 & $\begin{array}{l}26 / 8 \text { at } 15: 20 \\
\text { [Large } \\
\text { Branch] }\end{array}$ & $\begin{array}{l}\text { The plant seems } \\
\text { healthy. Just } \\
\text { undergone stress } \\
\text { because electrode } \\
\text { attached to other } \\
\text { branches. Soil is } \\
\text { less moist }\end{array}$ & $+9 \mathrm{v}$ & $1 \mu F$ & $9 \mu C$ & $\begin{array}{l}\text { The branch } \\
\text { spontaneously } \\
\text { droops at } \\
\text { pulvinus. Leaves } \\
\text { do not droop. }\end{array}$ & $\begin{array}{l}\text { The branch } \\
\text { became erect } \\
\text { after } 10 \mathrm{~min}\end{array}$ \\
\hline 7 & $\begin{array}{l}26 / 8 \text { at } 15: 43 \\
{[\text { Small branch] }}\end{array}$ & $\begin{array}{l}\text { The small branch } \\
\text { leaf is a little } \\
\text { weak. Soil is less } \\
\text { moist }\end{array}$ & $+9 \mathrm{v}$ & $1 \mu F$ & $9 \mu C$ & $\begin{array}{l}\text { No changes are } \\
\text { observed }\end{array}$ & $\begin{array}{l}\text { The branch } \\
\text { became erect } \\
\text { after 10min }\end{array}$ \\
\hline 8 & $\begin{array}{l}26 / 8 \text { at } 15: 44 \\
\text { [Small branch] }\end{array}$ & $\begin{array}{l}\text { The small branch } \\
\text { leaf is a little } \\
\text { weak. Soil is less } \\
\text { moist }\end{array}$ & $-9 v$ & $1 \mu F$ & $9 \mu C$ & $\begin{array}{l}\text { The branch } \\
\text { spontaneously } \\
\text { droops at } \\
\text { pulvinus. Leaves } \\
\text { droop } 2 \text { sec } \\
\text { after branch had } \\
\text { drooped. }\end{array}$ & $\begin{array}{l}\text { The branch } \\
\text { became erect } \\
\text { after } 6 \mathrm{~min}\end{array}$ \\
\hline 9 & $\begin{array}{l}26 / 8 \text { at } 17: 12 \\
{[\text { Small branch] }}\end{array}$ & $\begin{array}{l}\text { The small branch } \\
\text { is healthy. Soil is } \\
\text { less moist }\end{array}$ & $+9 \mathrm{v}$ & $10 \mu F$ & $0.00009 \mu C$ & $\begin{array}{l}\text { No changes are } \\
\text { observed }\end{array}$ & \\
\hline 10 & $\begin{array}{l}26 / 8 \text { at } 17: 12 \\
{[\text { Small branch] }}\end{array}$ & $\begin{array}{l}\text { The small branch } \\
\text { is healthy. Soil is } \\
\text { less moist }\end{array}$ & $-9 \mathrm{v}$ & $10 \mu F$ & $0.00009 \mu C$ & $\begin{array}{l}\text { No changes are } \\
\text { observed }\end{array}$ & \\
\hline 11 & $\begin{array}{l}26 / 8 \text { at } 17: 12 \\
{[\text { Small branch] }}\end{array}$ & $\begin{array}{l}\text { The small branch } \\
\text { is healthy. Soil is } \\
\text { less moist }\end{array}$ & $-9 \mathrm{v}$ & $1 n F$ & $0.009 \mu C$ & $\begin{array}{l}\text { No changes are } \\
\text { observed }\end{array}$ & \\
\hline 12 & $\begin{array}{l}26 / 8 \text { at } 17: 13 \\
\text { [Small branch] }\end{array}$ & $\begin{array}{l}\text { The small branch } \\
\text { is healthy. Soil is } \\
\text { less moist }\end{array}$ & $+9 \mathrm{v}$ & $1 n F$ & $0.009 \mu C$ & $\begin{array}{l}\text { No changes are } \\
\text { observed }\end{array}$ & \\
\hline 13 & $\begin{array}{l}26 / 8 \text { at } 17: 16 \\
{[\text { Small branch] }}\end{array}$ & $\begin{array}{l}\text { The small branch } \\
\text { is healthy. Soil is } \\
\text { less moist }\end{array}$ & $+9 \mathrm{v}$ & $100 n F$ & $0.9 \mu C$ & $\begin{array}{l}\text { No changes are } \\
\text { observed }\end{array}$ & \\
\hline 14 & $\begin{array}{l}26 / 8 \text { at } 17: 16 \\
{[\text { Small branch] }}\end{array}$ & $\begin{array}{l}\text { The small branch } \\
\text { is healthy. Soil is } \\
\text { less moist }\end{array}$ & $-9 v$ & $100 n F$ & $0.9 \mu C$ & $\begin{array}{l}\text { The branch } \\
\text { spontaneously } \\
\text { droops at } \\
\text { pulvinus. Leaves } \\
\text { are erect initially, } \\
\text { after 8s they are } \\
\text { closed }\end{array}$ & $\begin{array}{l}\text { The branch } \\
\text { became erect } \\
\text { after } 6 \mathrm{~min}\end{array}$ \\
\hline 15 & $\begin{array}{l}26 / 8 \text { at } 17: 17 \\
\text { [large branch] }\end{array}$ & $\begin{array}{l}\text { The large branch } \\
\text { is healthy. Soil is } \\
\text { less moist }\end{array}$ & $-9 v$ & $100 n F$ & $0.9 \mu C$ & $\begin{array}{l}\text { No changes are } \\
\text { observed }\end{array}$ & \\
\hline 16 & $\begin{array}{l}26 / 8 \text { at } 17: 17 \\
\text { [large branch] }\end{array}$ & $\begin{array}{l}\text { The large branch } \\
\text { is healthy. Soil is } \\
\text { less moist }\end{array}$ & $+9 \mathrm{v}$ & $100 n F$ & $0.9 \mu C$ & $\begin{array}{lr}\text { The } & \text { branch } \\
\text { droops } & \text { at } \\
\text { pulvinus } & \text { after } \\
\text { 1s. Leaves do not } \\
\text { droop }\end{array}$ & $\begin{array}{l}\text { The branch } \\
\text { became erect } \\
\text { after } 10 \mathrm{~min}\end{array}$ \\
\hline 17 & $\begin{array}{l}27 / 8 \text { at } 12: 30 \\
\text { [small branch] }\end{array}$ & $\begin{array}{l}\text { Leaves are only } \\
\text { partially open. } \\
\text { The plant is not } \\
\text { very healthy. }\end{array}$ & $+9 \mathrm{v}$ & $1 n F$ & $0.009 \mu C$ & $\begin{array}{l}\text { No changes are } \\
\text { observed }\end{array}$ & \\
\hline 18 & $\begin{array}{l}27 / 8 \text { at } 12: 31 \\
\text { [small branch] }\end{array}$ & $\begin{array}{l}\text { The plant is not } \\
\text { very healthy }\end{array}$ & $+9 \mathrm{v}$ & $10 n F$ & $0.09 \mu C$ & $\begin{array}{l}\text { No changes are } \\
\text { observed }\end{array}$ & \\
\hline 19 & $\begin{array}{l}27 / 8 \text { at } 12: 31 \\
\text { [small branch] }\end{array}$ & $\begin{array}{l}\text { The plant is not } \\
\text { very healthy }\end{array}$ & $+9 \mathrm{v}$ & $100 n F$ & $0.9 \mu C$ & $\begin{array}{l}\text { No changes are } \\
\text { observed }\end{array}$ & \\
\hline 20 & $\begin{array}{l}27 / 8 \text { at } 12: 32 \\
\text { [small branch] }\end{array}$ & $\begin{array}{l}\text { The plant is not } \\
\text { very healthy }\end{array}$ & $-9 v$ & $1 n F$ & $0.009 \mu C$ & $\begin{array}{ll}\text { No changes are } \\
\text { observed }\end{array}$ & \\
\hline 21 & $\begin{array}{l}27 / 8 \\
12: 35 \text { [small } \\
\text { branch] }\end{array}$ & $\begin{array}{l}\text { The plant is not } \\
\text { very healthy }\end{array}$ & $-9 \mathrm{v}$ & $10 n F$ & $0.09 \mu C$ & $\begin{array}{l}\text { No changes are } \\
\text { observed }\end{array}$ & \\
\hline 22 & $\begin{array}{l}27 / 8 \\
12: 35 \text { [small } \\
\text { branch] }\end{array}$ & $\begin{array}{l}\text { The plant is not } \\
\text { very healthy }\end{array}$ & $-9 \mathrm{v}$ & $100 n F$ & $0.9 \mu C$ & $\begin{array}{l}\text { No changes are } \\
\text { observed }\end{array}$ & \\
\hline 23 & $\begin{array}{l}27 / 8 \\
12: 36 \text { [small } \\
\text { branch] }\end{array}$ & $\begin{array}{l}\text { The plant is not } \\
\text { very healthy }\end{array}$ & $-9 \mathrm{v}$ & $1 \mu F$ & $9 \mu C$ & $\begin{array}{lr}\text { The } & \text { branch } \\
\text { droops } & \text { at } \\
\text { pulvinus } & \text { after } \\
2 \mathrm{~s} & \\
\end{array}$ & $\begin{array}{l}\text { The branch } \\
\text { became erect } \\
\text { after } 15 \mathrm{~min}\end{array}$ \\
\hline 24 & $\begin{array}{l}27 / 8 \\
12: 38[\text { large } \\
\text { branch] }\end{array}$ & $\begin{array}{l}\text { Leaves are only } \\
\text { partially open. } \\
\text { The plant is not } \\
\text { very healthy. }\end{array}$ & $+9 \mathrm{v}$ & $1 n F$ & $0.009 \mu C$ & $\begin{array}{l}\text { No changes are } \\
\text { observed }\end{array}$ & \\
\hline 25 & $\begin{array}{l}27 / 8 \\
12: 39[\text { large } \\
\text { branch] }\end{array}$ & $\begin{array}{l}\text { The plant is not } \\
\text { very healthy }\end{array}$ & $+9 \mathrm{v}$ & $10 n F$ & $0.09 \mu C$ & $\begin{array}{l}\text { No changes are } \\
\text { observed }\end{array}$ & \\
\hline
\end{tabular}




\begin{tabular}{|c|c|c|c|c|c|c|}
\hline 26 & $\begin{array}{l}27 / 8 \\
12: 39 \text { [large } \\
\text { branch] }\end{array}$ & $\begin{array}{l}\text { The plant is not } \\
\text { very healthy }\end{array}$ & $+9 \mathrm{v}$ & $100 n F$ & $0.9 \mu C$ & $\begin{array}{l}\text { No changes are } \\
\text { observed }\end{array}$ \\
\hline 27 & $\begin{array}{l}27 / 8 \\
12: 40 \text { [large } \\
\text { branch] }\end{array}$ & $\begin{array}{l}\text { The plant is not } \\
\text { very healthy }\end{array}$ & $+9 \mathrm{v}$ & $1 \mu F$ & $9 \mu C$ & $\begin{array}{l}\text { No changes are } \\
\text { observed }\end{array}$ \\
\hline 28 & $\begin{array}{l}27 / 8 \text { at [large } \\
\text { branch] }\end{array}$ & $\begin{array}{l}\text { The plant is not } \\
\text { very healthy }\end{array}$ & $+9 \mathrm{v}$ & $47 \mu F$ & $423 \mu C$ & $\begin{array}{l}\text { No changes are } \\
\text { observed }\end{array}$ \\
\hline 29 & $\begin{array}{l}27 / 8 \\
12: 41 \text { [large } \\
\text { branch] }\end{array}$ & $\begin{array}{l}\text { The plant is not } \\
\text { very healthy }\end{array}$ & $-9 v$ & $1 n F$ & $0.009 \mu C$ & $\begin{array}{l}\text { No changes are } \\
\text { observed }\end{array}$ \\
\hline 30 & $\begin{array}{l}27 / 8 \\
12: 41 \text { [large } \\
\text { branch] }\end{array}$ & $\begin{array}{l}\text { The plant is not } \\
\text { very healthy }\end{array}$ & $-9 \mathrm{v}$ & $10 n F$ & $0.09 \mu C$ & $\begin{array}{l}\text { No changes are } \\
\text { observed }\end{array}$ \\
\hline 31 & $\begin{array}{l}27 / 8 \\
12: 41 \text { [large } \\
\text { branch] }\end{array}$ & $\begin{array}{l}\text { The plant is not } \\
\text { very healthy }\end{array}$ & $-9 \mathrm{v}$ & $100 n F$ & $0.9 \mu C$ & $\begin{array}{l}\text { No changes are } \\
\text { observed }\end{array}$ \\
\hline 32 & $\begin{array}{l}27 / 8 \\
12: 42 \text { [large } \\
\text { branch] }\end{array}$ & $\begin{array}{l}\text { The plant is not } \\
\text { very healthy }\end{array}$ & $-9 v$ & $1 \mu F$ & $9 \mu C$ & $\begin{array}{l}\text { No changes are } \\
\text { observed }\end{array}$ \\
\hline 33 & $\begin{array}{l}27 / 8 \\
12: 42 \text { [large } \\
\text { branch] }\end{array}$ & $\begin{array}{l}\text { The plant is not } \\
\text { very healthy }\end{array}$ & $-9 v$ & $47 \mu F$ & $423 \mu C$ & $\begin{array}{l}\text { The branch } \\
\text { spontaneously } \\
\text { droops at } \\
\text { pulvinus }\end{array}$ \\
\hline 34 & $\begin{array}{l}27 / 8 \text { at } 4: 25 \text { [small } \\
\text { branch] }\end{array}$ & $\begin{array}{l}\text { The plant looks } \\
\text { much healthier. } \\
\text { Leaves are still } \\
\text { not completely } \\
\text { open. But they } \\
\text { are more erect } \\
\text { than at } 12: 40\end{array}$ & $-9 v$ & $10 n f$ & $0.09 \mu C$ & $\begin{array}{l}\text { No changes are } \\
\text { observed }\end{array}$ \\
\hline 35 & $\begin{array}{l}27 / 8 \text { at } 4: 25 \text { [small } \\
\text { branch] }\end{array}$ & $\begin{array}{l}\text { The plant looks } \\
\text { much healthier }\end{array}$ & $-9 v$ & $100 n F$ & $0.9 \mu C$ & $\begin{array}{l}\text { Branch } \\
\text { Spontaneously } \\
\text { droops at } \\
\text { pulvinus }\end{array}$ \\
\hline 36 & $\begin{array}{l}27 / 8 \text { at } 4: 28 \text { [large } \\
\text { branch] }\end{array}$ & $\begin{array}{l}\text { The plant looks } \\
\text { much healthier }\end{array}$ & $-9 \mathrm{v}$ & $100 n F$ & $0.9 \mu C$ & $\begin{array}{l}\text { Branch } \\
\text { Spontaneously } \\
\text { droops at } \\
\text { pulvinus }\end{array}$ \\
\hline
\end{tabular}




\section{Observations}

We have noted that the charge from at least a $100 \mathrm{nF}$ capacitor is required to evoke an action potential in the plant.

The minimum charge required to trigger a response is given by

$$
C * V=9 v * 100 n F=0.9 \mu C
$$

\subsection{Further Observations}

We have made some further observations which we note here,

1. Most of the time, when an external electrical signal is given in the mentioned manner to the plant, only the petiole droops and the pinnae mostly remain erect.

2. It is also noted that sometimes a forward potential is required to trigger a response in the plant, and sometimes a reverse potential. No regular pattern associated with this behavior was observed.

3. When the plant is exposed to stress or is not healthy, the amount of charge required to trigger an action potential differs from the amount required to trigger when the plant is healthy.

4. When electrode gel is applied at the pulvinus connection, then the petiole never droops. This might be because as the electrode gel is a hypotonic medium, it might not allow the cells to lose turgidity thus, not letting it droop.

\section{Concluding Remarks}

1. An external electrical signal can indeed trigger an action potential and make the petiole of an $M$. pudica plant droop at the pulvinus.

2. A minimum of $0.9 \mu C$ of charge is required to trigger an action potential.

From this experiment, we can conclude that, by applying a potential difference across the ground and pulvinus, it is possible to make the $M$. pudica plant droop its petiole even without physically touching it. So this proves the fact that thigmonastic behavior in M. pudica plants is, in fact, associated with electrical signals that are naturally produced in the plant. It was also further found out that a minimum of at least $0.9 \mu \mathrm{C}$ of charge is required to trigger an action potential. However, when the physiology of the plant is disturbed due to environmental stress, then the threshold charge is also altered. The exact change in threshold charge can be calculated by conducting more experiments in the future. 


\section{Bibliography}

[1] Alexander G Volkov, Justin C. Foster, Talitha A. Ashby, Ronald K. Walker, Jon A. Johnson \& Vladislav S. Markin (2010) Mimosa pudica: Electrical and mechanical stimulation of plant movements; Wiley Online Library 332.

[2] Balmer R.T. \& Franks J.G. (1975) Contractile characteristics of Mimosa pudica L. Plant Physiology 56, 464- 467 .

[3] Jonas H. (1970) Oscillations and movements of Mimosa leave due to electric shock. Journal of Interdisciplinary Cycle Research 1, 335-348.

[4] Gardiner W. (1888) On the power of contractility exhibited by the protoplasm of certain plant cells. Annals of Botany os-1, 362-367.

[5] Ritter J.W. (1811) Electrische Versuche an der Mimosa pudica L. In Parallel mit gleichen Versuchen an Fröschen. Denkschr Köningl Akad Wiss (München) 2, 345- 400.

[6] Yao H., Xu Q. \& Yuan M. (2008) Actin dynamics mediates the changes of calcium level during the pulvinus movement of Mimosa pudica. Plant Signaling and Behavior 3, 954-960. 